\title{
Comparison of Solar Maximum Power Tracking Methods for Stand Alone Solar Photo-voltaic System
}

\author{
P. S. Revankar \\ Research Scholar, Professor \\ Prof. \& Director CIT, YASHADA \\ Pune (M. S.) India
}

\author{
W. Z. Gandhare, PhD \\ Former Principal \\ Govt. College of Engineering, \\ Amravati (M. S.) India
}

\begin{abstract}
Maximum Power Point Tracker (MPPTs) play a major role in photovoltaic (PV) power systems because they maximize power output from a PV system for a given set of conditions, and thereby maximizing the array efficiency. The paper presents the comparison of solar maximum power tracking methods for a stand-alone solar PV system. The I-V \& P-V characteristics are obtained for different values of solar insolation by maintaining the cell temperature constant. The solar MPPT methods are responsible for deriving maximum possible power from photovoltaic module to the load via a boost converter used for stepping up the voltage to required magnitude. The main aim will be to track the maximum power point of the photovoltaic module to extract maximum power. The Maximum Power Point Tracking (MPPT) algorithms, which are based on the incremental conductance method and Perturb and Observe method, are also described. Both these algorithms are applied to stand-alone system feeding to $1 \mathrm{kw}$ load. The simulation results were presented to validate that the Incremental conductance approach has better steady state performance than the traditional $\mathrm{P}$ and $\mathrm{O}$ under various conditions along with improved efficiency of the PV system. The algorithm structure was built using MATLAB Simulink software.
\end{abstract}

\section{Keywords}

Perturb and Observe, Incremental conductance, MPPT, MATLAB/Simulink

\section{INTRODUCTION}

Abundantly available Solar Energy is a great natural wealth which can be harvested and utilized for energy requirements of community. Solar power system can be a standalone or can be a grid connected generating unit. It is attractive solution to power rural areas where grid is not available nearby. Due to its portable operation we can use it whenever and wherever necessary. In order to address present energy challenges, we need to develop an efficient way in which power can be extracted from solar radiation. In past few years, the size of power conversion units has been greatly reduced. Research in power electronics and materials has greatly helped to come up small; yet powerful systems to withstand high power demand. One of the disadvantages of these systems is increased power density. Therefore, new trend is set for using multi-input converters which can handle voltage fluctuations. But owing to their high production costs and relatively low efficiency, these systems can hardly compete in markets as prime power generation source.

Fundamental power conversion unit of a PV generator system is represented by PV module. Output characteristics of PV module is dependent on solar insolation, cell temperature and output voltage the module. The PV module has nonlinear characteristics, which makes it necessary to model for simulation of maximum power point tracking (MPPT). Mathematical PV models for simulation have been developed. In a PV model, the output characteristics of PV module is affected by solar insolation, cell temperature, and load voltage. As most of the simulation packages including SIM Power System tool of MATLAB package do not offer solutions to analyze and model PV power system, which has motivated us to develop a model for PV cell, module and the array using Simulink of MATLAB. [1]

\section{SOLAR MAXIMUM POWER TRACKING SYSTEM}

\subsection{Solar panel modeling}

A general mathematical description of I-V output characteristics for a PV cell is being studied for long time. The equivalent circuit-based model is mainly used for analysis. The equivalent circuit consists of a photo current, a diode, a parallel resistor expressing a leakage current, and a series resistor as an internal resistance to the current flow, is shown in Fig. 1(a). The voltage-current characteristic equation of a solar cell is given as

$$
I=I_{p h}-I_{S}\left[\exp \left(\frac{q\left(V+I R_{S}\right)}{k T_{S} A}\right)-1\right]
$$

Where $I_{p h}$ is $\mathrm{r}$ photocurrent, $I_{s}$ is the cell saturation of dark current, $\mathrm{q}\left(=1.6 \times 10^{-19} \mathrm{C}\right)$ is an electron charge, $\mathrm{k}(=1.38$ $\times 10-23 \mathrm{~J} / \mathrm{K})$ is a Boltzmann's constant, $\mathrm{T}_{\mathrm{s}}$ is the cell's working temperature, $\mathrm{A}$ is an ideal factor, Rsh is a shunt resistance, and Rs is a series resistance. The photocurrent largely depends on the solar insolation and cell's working temperature, which is described as

$$
I_{p h}=\left[I_{s c}+k_{I}\left(T_{c}-T_{r e f}\right)\right] \lambda
$$

where $I_{s c}$ is the cell's short-circuit current at a $25^{\circ} \mathrm{C}$ and $1 \mathrm{~kW} / \mathrm{m}^{2}, k_{I}$ is the cell's short-circuit current temperature coefficient, $T_{r e f}$ is the cell's reference temperature, and $\lambda$ is the solar insolation in $\mathrm{kW} / \mathrm{m} 2$. [1]

\subsection{Solar MPPT Method}

The atmospheric conditions and the load changes cause operation parameters of a PV system to vary. A dynamic tracking technique is important to ensure that maximum power is extracted from photovoltaic arrays. The following algorithms are in use as most used MPPT algorithms. These algorithms can be built in micro-controller based systems. 
MPPT algorithm operates based on the principle of Maximum Power Transfer, where derivative of the output power $(\mathrm{P})$ with respect to the panel voltage $(\mathrm{V})$ is equal to zero at the maximum power point. Most widely used MPPT algorithms are discussed here, they are:

1. Perturb and Observe $(\mathrm{P} \& \mathrm{O})$

2. Incremental Conductance (In Cond)

3. Constant Voltage Method.

Figure 1 shows the $I-V$ characteristics of a solar cell. A PV array comprises of PV cells connected into a unit to get suitable power rating. The output parameters of PV cell array are decided by multiplying voltage of an individual PV cell by number of cells connected in series and multiplying current by number of cells connected in parallel. There are three important operating points of PV cell array namely, opencircuit voltage, short circuit current and Maximum Power Point.

The operating point of PV array under constant irradiance and cell temperature is the intersection point of the $I-V$ characteristics and the load characteristics. A straight line with gradient $M=1 / R=I_{\text {Load }} / V_{\text {load }}$ shown in figure 2 which represents the load characteristic.

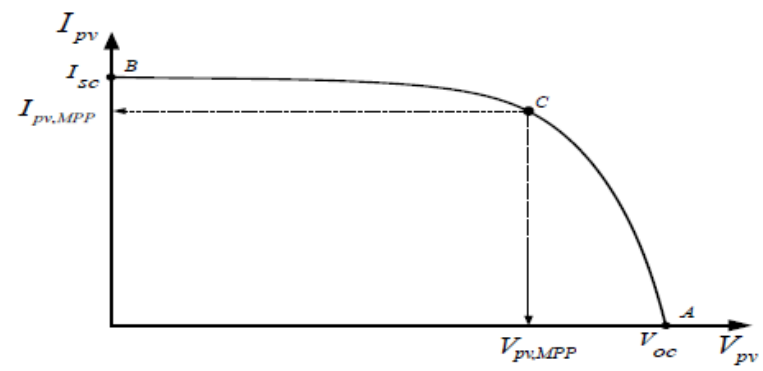

Fig. 1 Solar panel I-V characteristics

The system operating point moves along $I-V$ characteristic curve of the $\mathrm{PV}$ panel, from point $\mathrm{B}$ on curve to point $\mathrm{A}$, as the load resistance increases from zero to infinity. Maximum Power Point is at $\mathrm{C}$, where the area under the $I-V$ curve is maximum. For higher load resistances, the operating points go into the CA region, and for lower load resistances, the operating points go into $\mathrm{CB}$ region on the curve. Maximum Power Point can be obtained by matching load resistance to PV array characteristics.

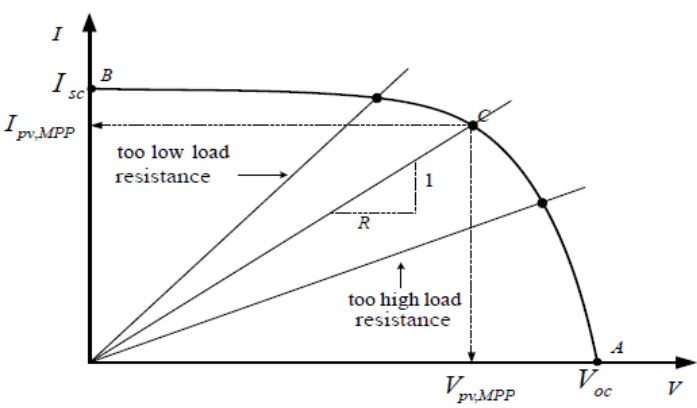

Fig. 2 Solar panel I-V Characteristics showing load characteristics

A. Perturb and Observe (P\&O)
Commonly used Maximum Power Point Tracking algorithm is Perturb and Observe (P\&O) method. In this algorithm, module voltage is given a perturbation at periodic intervals and then the output power is compared with the power at the previous perturbation cycle.

In Figure 2, we see that decreasing voltage on right side of Maximum Power Point increases power. Also, increasing voltage on the left side of Maximum Power Point increases power. This is the operating principle of $\mathrm{P} \& \mathrm{O}$ algorithm. After increasing operating voltage, the algorithm compares the current power reading with the power reading in previous sampling cycle.

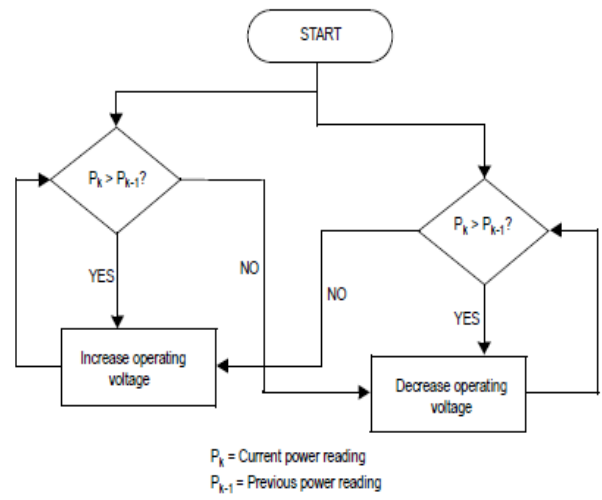

Fig. 3 P \& O Algorithm [9]

If output power demonstrates incremental rise, the algorithm continues in the direction of increasing voltage, otherwise reverses direction towards decreasing voltage. The process is repeated at every tracking step until the Maximum Power Point is reached. At point of Maximum Power, the P\&O algorithm oscillates around the correct value of Maximum Power. In P\&O Algorithm fixed step size is used to increase or decrease the voltage till the point of maximum power is achieved..

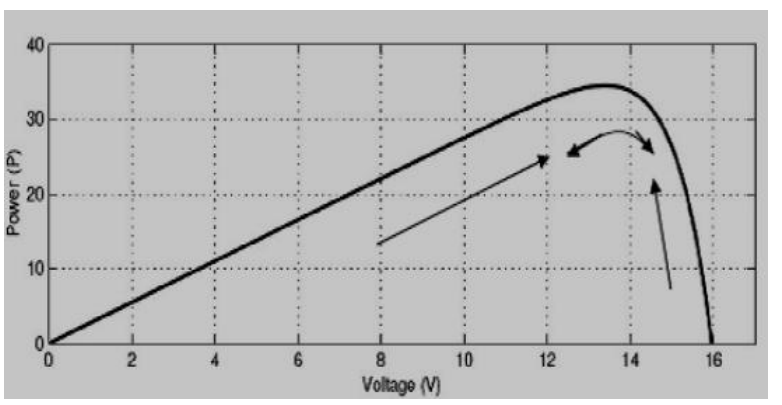

Fig 4. Output Power versus Voltage for P\&O Algorithm

In $\mathrm{P} \& \mathrm{O}$ algorithm slight perturbation is introduced to the system. This perturbation causes the power of the solar module to vary. If output power increases due to this perturbation then perturbation is continued in the same direction. After peak power is reached the power at the Maximum Power Point, the perturbation reverses as shown in Figure 4 . When a stable condition is arrived, the algorithm oscillates around the maximum power point. In order to maintain the power variation small the perturbation size is kept small. The technique is implemented to set a reference voltage of PV module to the peak voltage of the module. A PI controller then works to transfer the operating point of the module to that particular voltage level.

B. Incremental Conductance 
At maximum power point, the PV module power curve derivative versus voltage is zero, the same is positive on the left side and negative on the right side of the Maximum Power Point. The incremental conductance algorithm uses this fact in its implementation.

The incremental conductance $(\Delta I / \Delta V)$ is compared in this algorithm with the instantaneous conductance $(I / V)$. As outcome of this comparison, the panel operating voltage is either increased, or decreased until Maximum Power Point is reached. When compared with Perturb and Oscillate algorithm, which oscillates around the point of maximum power, incremental conductance algorithm stops modifying the operating voltage; when a correct value is reached. Any change in PV module current will restart the algorithm for tracking maximum power point. As per the ambient conditions, the same functionality may be achieved by using the initial equation $(\Delta P / \Delta V)$.

The following are the set of equations which describes the incremental conductance method.

\section{Conditions for MPP}

$\frac{d P}{d V}=0, a t M P P$

$\frac{d P}{d V}>0$, at left of $M P P$

$\frac{d P}{d V}<0$, at right of $M P P$

$\frac{d P}{d V}=\frac{d(I V)}{d V}=I \frac{d V}{d V}+V \frac{d I}{d V}=I+V \frac{d I}{d V}$

$\frac{\Delta I}{\Delta V}=\frac{I}{V}$, at $M P P$

$\frac{\Delta I}{\Delta V}>-\frac{I}{V}$, at left of $M P P$

$\frac{d P}{d V}<-\frac{I}{V}$, at right of $M P P$

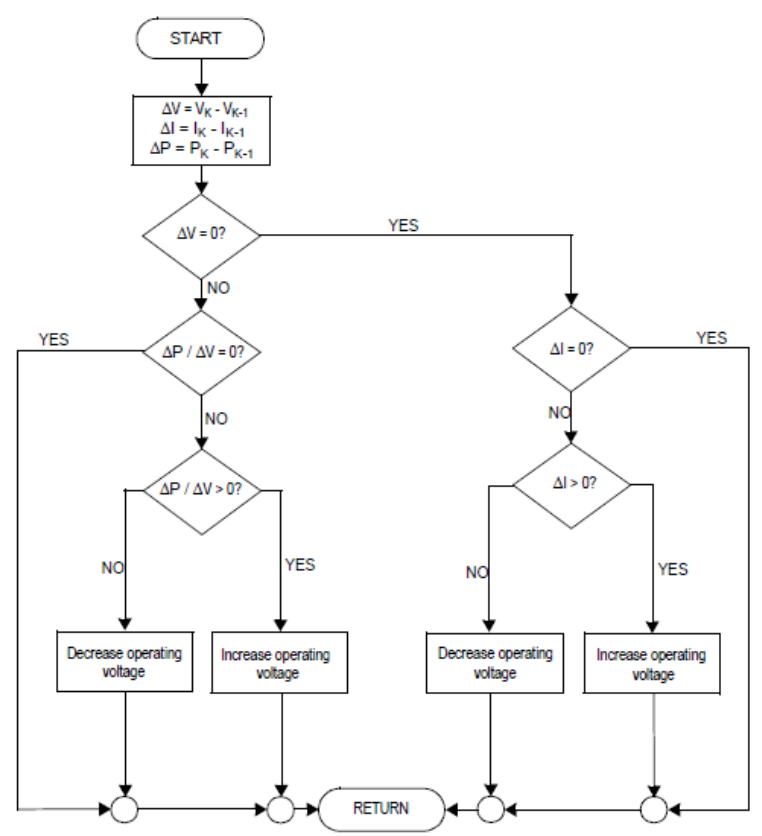

Fig. 5. Incremental Conductance algorithm
If a larger step size is used, the tracking will be faster but may cause the algorithm to oscillate around the maximum power point instead of getting locked to the correct value. Incremental conductance algorithm requires output voltage and current values from sensors at PV module. As this algorithm requires values of previous step output voltage and current, it is usually implemented using advanced microcontroller or a Digital Signal Processor.

\section{STAND ALONE SOLAR PV SYSTEM}

The solar PV cell is modeled in MATLAB/Simulink and it is connected to boost converter. A boost converter is a commonly used circuit to step up the voltage from a dc source, while a buck converter is often used to step down voltage.

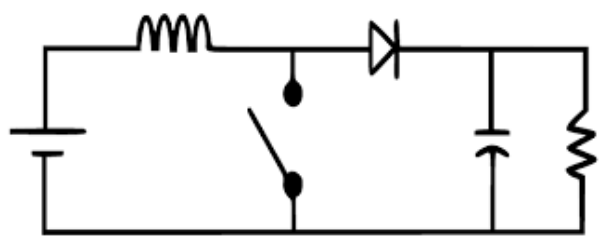

Fig. 6 Boost converter

A boost converter raises a dc voltage from its source to the dc voltage is needed by the load. In figure 6 , source is a PV module and the load is shown as a resistance, a basic concept which is used for variety of electric power applications. The power semiconductor switch flips on and off at a rapid rate of around $20 \mathrm{kHz}$ under the control of some sensing and logic circuit. The duty cycle of boost converter is determined by Maximum Power Point Tracking algorithm to track the maximum power point of the system.

\subsection{Basic Block Diagram}

Grid-connected systems are used for back-up, usually there is no need for battery storage. Therefore they become relatively simple and inexpensive. However, they have to compete with relatively inexpensive utility power. When there is no grid nearby, electricity becomes a valuable resource and then the extra cost and complexity of a totally self-sufficient, standalone power system is justifiable.

In this case, a stand-alone solar PV system consisting of solar $\mathrm{PV}$ array, DC-DC converter feeding to $1 \mathrm{~kW}$ resistive load is considered. The solar panel characteristics are given below

Table1: Solar Panel Characteristics

\begin{tabular}{|l|l|}
\hline Parameter & Value \\
\hline $\mathrm{V}_{\mathrm{oc}}$ & 21.24 Volts \\
\hline $\mathrm{I}_{\mathrm{sc}}$ & 2.55 Amp \\
\hline $\mathrm{V}_{\mathrm{mp}}$ & 16.56 Volts \\
\hline $\mathrm{I}_{\mathrm{mp}}$ & 2.25 Amp \\
\hline $\mathrm{R}_{\mathrm{s}}$ & 0.47 ohm \\
\hline $\mathrm{R}_{\mathrm{p}}$ & $145.672 \mathrm{ohm}$ \\
\hline
\end{tabular}


Following figure shows basic block diagram of stand-alone solar MPPT system supplying to $1 \mathrm{~kW}$ load. Solar MPPT controller tracks the maximum power point and adjusts the duty cycle of boost converter to transfer the maximum power from solar PV module to the load.

The MATLAB based simulation is carried out to analyze the the system. Mathematical modeling of solar PV array and DCDC converter is carried out. Duty cycle of converter is set by the MPPT controller which uses perturb and observe as well as incremental conductance method.

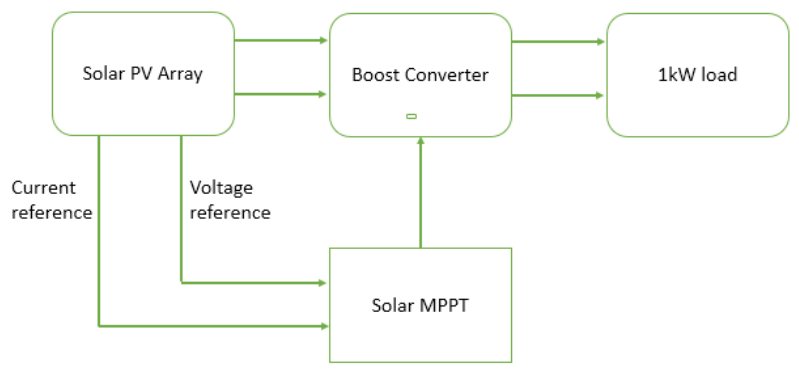

Fig. 7 Block diagram of stand-alone solar PV system

\subsection{Simulation of Perturb and observe Method}

The use of equivalent electrical circuit helps to model characteristics of a photovoltaic cell. The method used here is implemented in MATLAB/Simulink software for simulations. The same modeling technique is also applicable for modeling a PV module. A modeling of $1 \mathrm{KW}$ stand-alone solar PV system.

With perturb and observe method is carried out. The standard insolation of $1 \mathrm{~kW} / \mathrm{m}^{2}$ and ambient temperature of $25^{\circ} \mathrm{C}$ is considered.

A simple boost converter is modeled in MATLAB/Simulink. The boost converter consists of an inductor, a switch, a diode, and a capacitor as shown in Fig. 8. Boost converter circuit works in two modes. Mode 1 starts when switch is turned on at $\mathrm{t}=$ Ton. Rising input current flows through inductor $\mathrm{L}$ and switch, causing energy being stored in the inductor. Mode 2 begins when the switch is turned off at $t=$ Toff. The current flowing through the switch will now take its path through inductor $\mathrm{L}$, diode $\mathrm{D}$, capacitor $\mathrm{C}$, and load $\mathrm{R}$. The inductor current falls until the switch is turned on again in the next cycle.

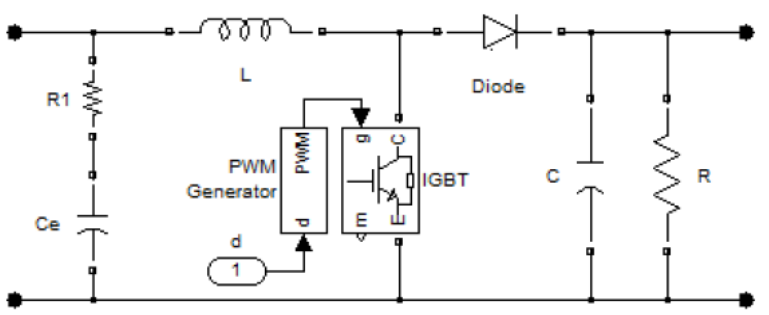

Fig. 8 Boost converter model in MATLAB/Simulink[12]

Energy stored in the inductor is transferred to the load. Therefore, the output voltage is greater than the input voltage and is expressed as in equation below

$$
V_{\text {out }}=\frac{1}{(1-D)} V_{\text {in }}
$$

\subsection{Result from Perturb and Observe method at standard Insolation}

The figure 9 below shows the current waveform from the solar PV and current from boost converter controlled by $\mathrm{P}$ and $\mathrm{O}$ algorithm at standard insolation.
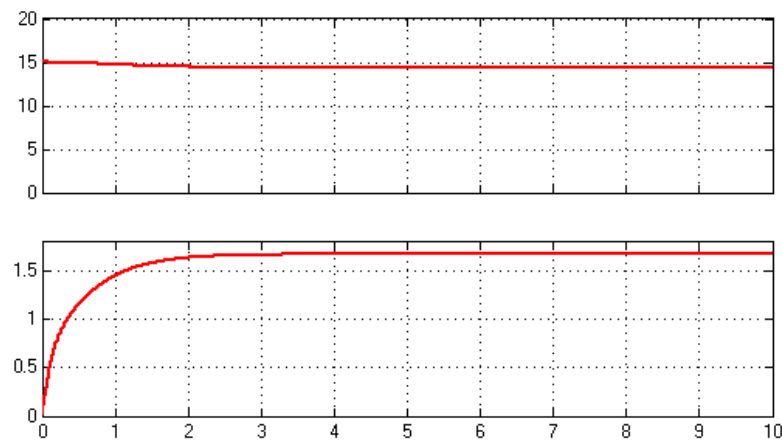

Fig. 9 current from solar PV and current from boost converter

The figure 10 below shows the voltage waveform from the solar PV and voltage from boost converter at standard insolation. The solar PV voltage rises to 90 volts and it is steeped upto 600 volts.
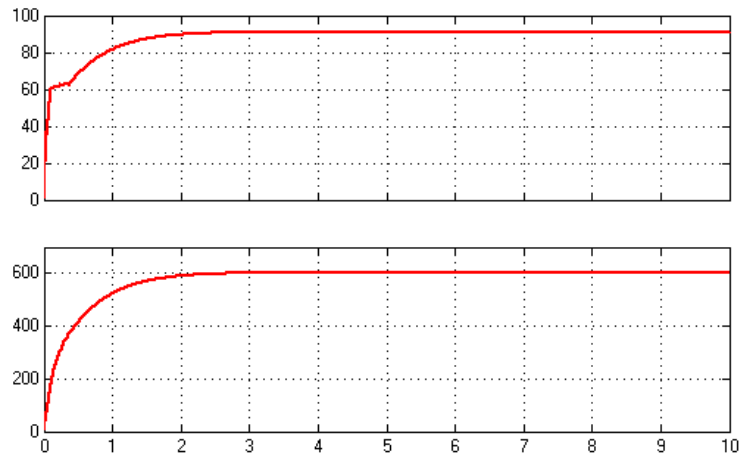

Fig. 10 voltage from solar PV and voltage from boost converter

The figure 11 below shows the power waveform from the solar PV and power from boost converter at standard insolation
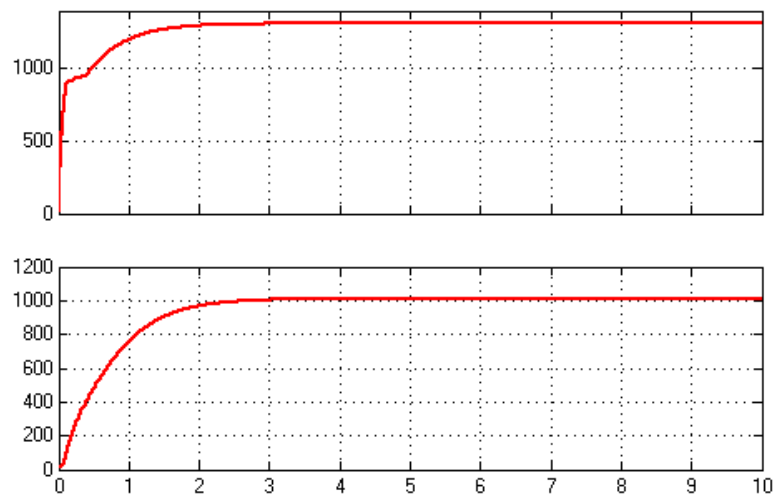

Fig. 11 power from solar $P V$ and power from boost converter 


\subsection{Result from Perturb \& Observe method at Variable Insolation}

The amount of sunlight falling on a specific geographical location is known as insolation or incident solar radiation. Insolation depends on the following factors:

1. The angle at which solar radiation strikes a surface

2. Climate zones, seasonal temperature changes \& daily temperature

\section{Latitude}

The performance of the PV panel depends on the surrounding temperature, insolation and climate of the place. As the solar insolation keeps on changing throughout the day, similarly I$\mathrm{V}$ and $\mathrm{P}-\mathrm{V}$ characteristics also vary. With the increasing solar irradiance both the open circuit voltage and the short circuit current increases and hence the maximum power point varies.

During this experimentation, effect of change on solar insolation to change the MPP is demonstrated. Solar insolation is changed from standard $1000 \mathrm{~W} / \mathrm{m}^{2}$ to $800 \mathrm{~W} / \mathrm{m}^{2}$, further it is reduced to $600 \mathrm{~W} / \mathrm{m}^{2}$.

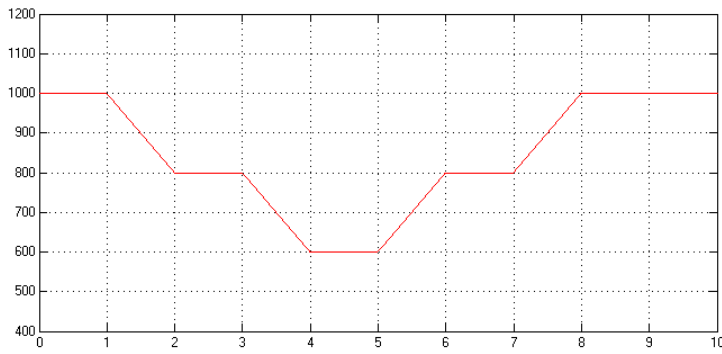

Fig. 12 Variation in insolation

The figure 13 shows current waveform from the solar PV system. It is seen that as the insolation falls, current output also falls. When insolation falls from $1000 \mathrm{~W} / \mathrm{m}^{2}$ to $800 \mathrm{~W} / \mathrm{m}^{2}$ , the current also falls from 15 Amps to 12 Amps.
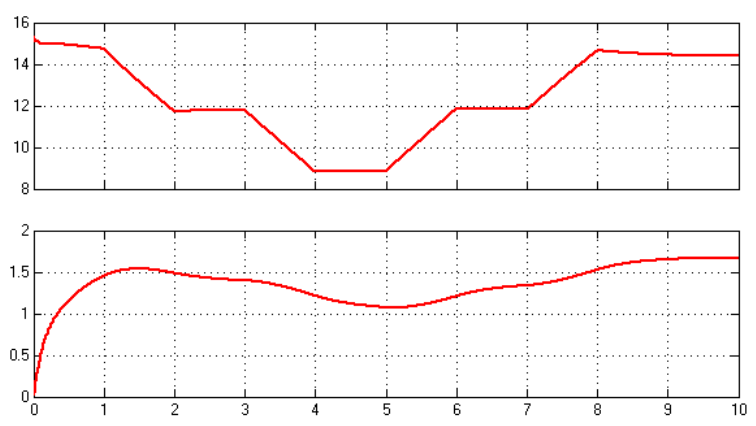

Fig. 13 current from solar PV and current from boost converter

The figure 14 shows the output voltage waveform from solar PV. It is seen that as insolation falls from $1000 \mathrm{~W} / \mathrm{m}^{2}$ to 800 $\mathrm{W} / \mathrm{m}^{2}$, voltage reduces to 78 volts from 90.95 volts.
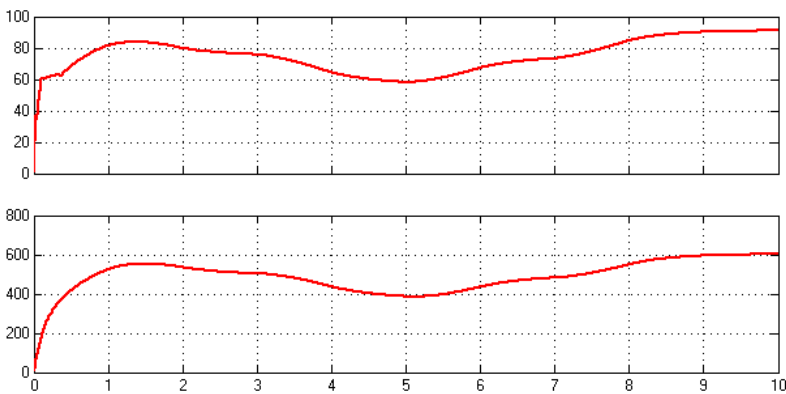

Fig. 14 voltage from solar PV and voltage from boost converter

\subsection{Simulation of Incremental Conductance Method}

Incremental Conductance method is more efficient when compared with Perturb and Observe method because terminal voltage is changed to its value relative to the Maximum Power Point voltage. The Incremental Conductance method offers better performance under changing atmospheric conditions.

This algorithm has advantages over $\mathrm{P} \& \mathrm{O}$ in that it can determine when the MPPT has reached the point of maximum power. The figure shown is of the modeling of $1 \mathrm{~kW}$ standalone solar PV system with perturb and observe method. The simulation is carried out with standard insolation of $1 \mathrm{~kW} / \mathrm{m}^{2}$ and ambient temperature of $25^{\circ} \mathrm{C}$.

\subsection{Result from Incremental Conductance Method at Standard Insolation}

The figure 15 below shows the current waveform from the solar PV and current from boost converter controlled by incremental conductance algorithm at standard insolation.
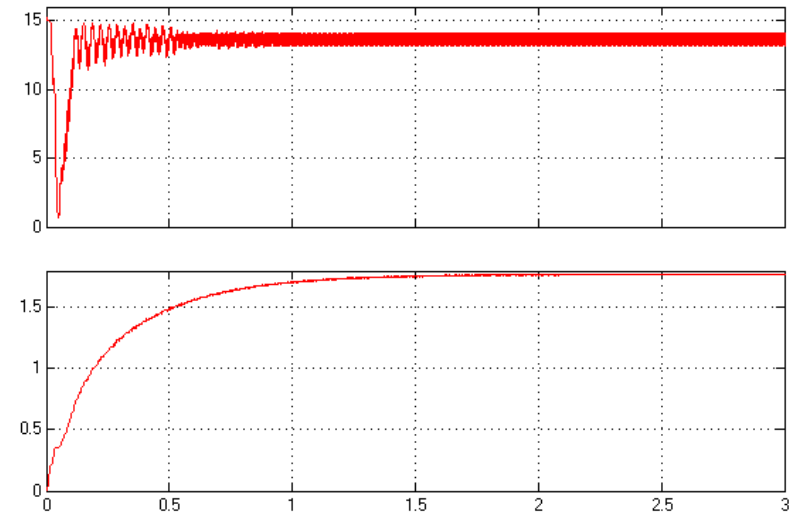

Fig. 15 current from solar PV and current from boost converter

The figure 16 below shows the voltage waveform from the solar PV and voltage from boost converter at standard insolation. The solar PV voltage rises to 101 volts and it is steeped up to 640 volts 

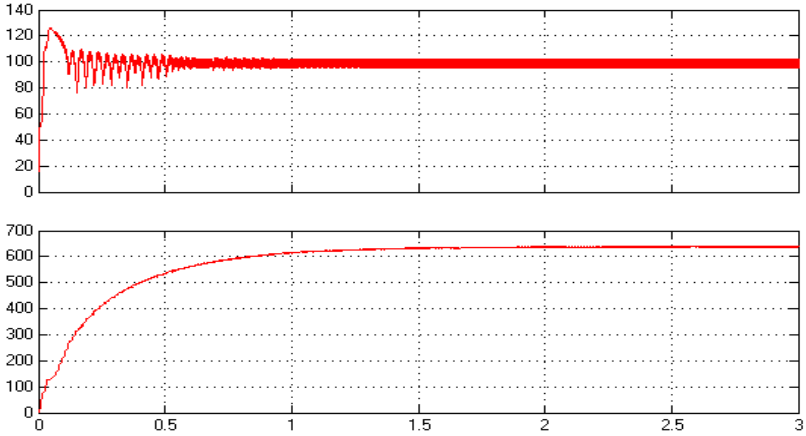

Fig. 16 voltage from solar PV and voltage from boost converter

The figure 17 below shows the power waveform from the solar PV and power from boost converter at standard insolation
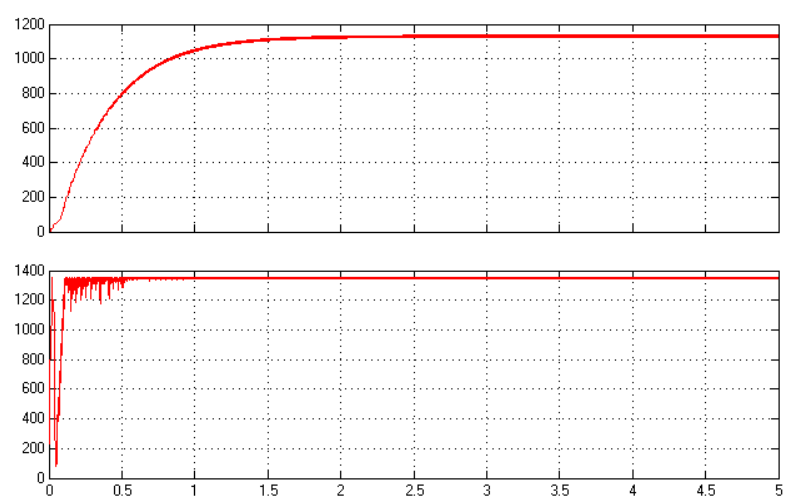

Fig. 17 power from solar $P V$ and power from boost converter

\subsection{Simulation of Incremental Conductance Method at Variable Insolation}

The figure 18 shows current waveform from the solar PV system controlled by incremental conductance algorithm. It is seen that as the insolation falls, current output also falls. When insolation falls from $1000 \mathrm{~W} / \mathrm{m}^{2}$ to $800 \mathrm{~W} / \mathrm{m}^{2}$ and it further falls to $600 \mathrm{~W} / \mathrm{m}^{2}$, the current also falls from 13.5 Amps to 10.9 Amps.
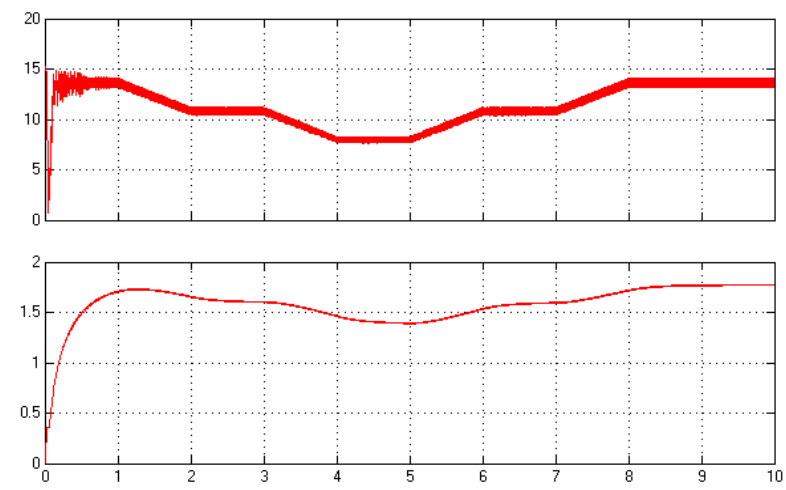

Fig. 18 current from solar PV and current from boost converter
The figure 19 shows the output voltage waveform from solar $\mathrm{PV}$. It is seen that as insolation falls from $1000 \mathrm{~W} / \mathrm{m}^{2}$ to 800 $\mathrm{W} / \mathrm{m}^{2}$, voltage reduces to 98 volts from 101 volts. The incremental conductance method controls duty cycle of boost converter to transfer the maximum power from the solar PV system.

The figure 20 below shows the power waveform from the solar PV and power from boost converter controlled by incremental conductance at variable insolation. It is seen that the power output from solar PV is a function of solar insolation. As the insolation reduces, the power output from the solar PV also reduces.
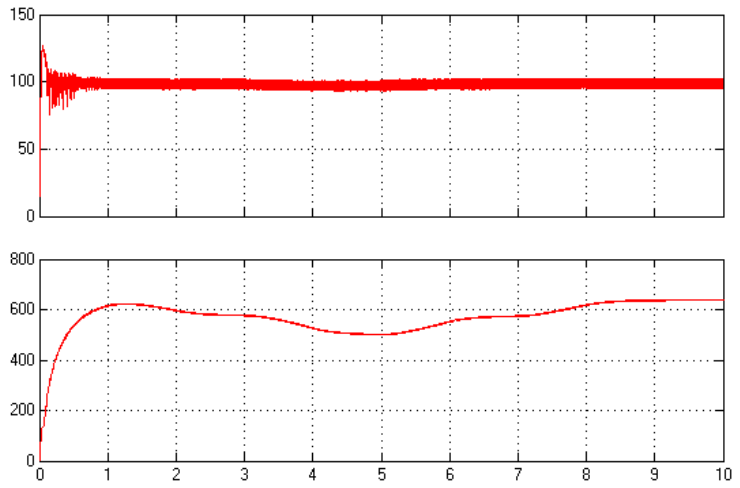

Fig. 19 voltage from solar PV and voltage from boost converter
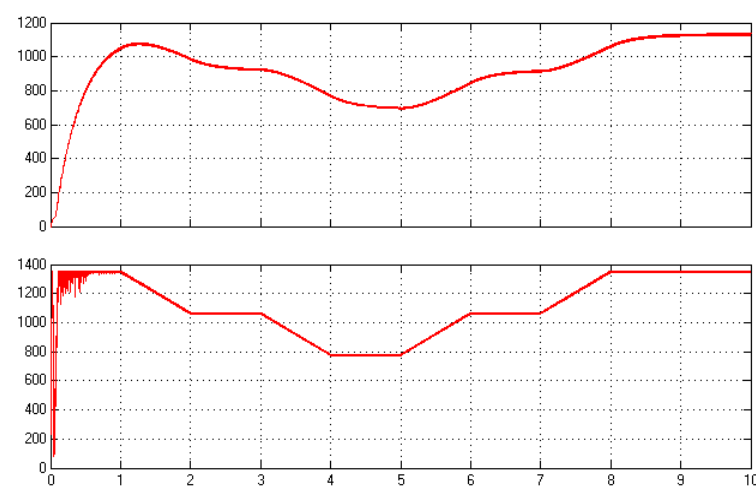

Fig. 20 power from solar $\mathrm{PV}$ and power from boost converter

\section{RESULT ANALYSIS}

\subsection{P \& O Results}

Following table shows the performance analysis of standalone solar PV system which uses P \& O method.

Table 2 Performance of $\mathbf{P} \& \mathbf{O}$ method at standard insolation.

\begin{tabular}{|c|c|c|c|c|c|c|}
\hline $\begin{array}{l}\text { Solar } \\
\text { Insolatio } \\
\mathrm{n}\end{array}$ & $V_{P v}$ & $I_{P v}$ & $V_{\text {boost }}$ & $I_{\text {boost }}$ & $P_{P v}$ & $P_{\text {boost }}$ \\
\hline $\begin{array}{l}1000 \\
W / m^{2}\end{array}$ & $\begin{array}{l}90.95 \\
\text { Volts }\end{array}$ & $\begin{array}{l}14.4 \\
\text { Amp }\end{array}$ & $\begin{array}{l}603.3 \\
\text { Volts }\end{array}$ & $\begin{array}{l}1.676 \\
\text { Amp }\end{array}$ & $\begin{array}{l}1309 \\
\text { Watt }\end{array}$ & $\begin{array}{l}1011 \\
\text { Watt }\end{array}$ \\
\hline
\end{tabular}


Table 3 Performance of $\mathbf{P} \& \mathbf{O}$ method at variable insolation

\begin{tabular}{|c|c|c|c|}
\hline $\begin{array}{c}\text { Solar } \\
\text { Insolation }\end{array}$ & $V_{P v}$ & $I_{P v}$ & $P_{P v}$ \\
\hline $1000 \mathrm{~W} / \mathrm{m}^{2}$ & 90.95 Volts & $14.4 \mathrm{Amp}$ & 1309 Watt \\
\hline $800 \mathrm{~W} / \mathrm{m}^{2}$ & 78 Volts & $11.7 \mathrm{Amp}$ & $912.6 \mathrm{Watt}$ \\
\hline $600 \mathrm{~W} / \mathrm{m}^{2}$ & 60 Volts & $8.84 \mathrm{Amp}$ & 530 Watt \\
\hline
\end{tabular}

\subsection{Incremental Conductance Results}

Following table shows the performance analysis of standalone solar PV system which uses IC method.

Table 4 Performance of IC method at standard insolation

\begin{tabular}{|l|l|l|l|l|l|l|}
\hline $\begin{array}{l}\text { Solar } \\
\text { Insolatio } \\
\mathrm{n}\end{array}$ & $V_{P v}$ & $I_{P v}$ & $V_{\text {boost }}$ & $I_{\text {boost }}$ & $P_{P v}$ & $P_{\text {boost }}$ \\
\hline 1000 & $\begin{array}{l}101 \\
\mathrm{~W} / \mathrm{m}^{2}\end{array}$ & $\begin{array}{l}13.5 \\
\text { Volts }\end{array}$ & $\begin{array}{l}\text { Amp } \\
\text { Volts }\end{array}$ & $\begin{array}{l}1.790 \\
\text { Amp }\end{array}$ & $\begin{array}{l}1350 \\
\text { Watt }\end{array}$ & $\begin{array}{l}1130 \\
\text { Watt }\end{array}$ \\
\hline
\end{tabular}

Table 5 Performance of IC method at variable insolation

\begin{tabular}{|l|c|c|c|}
\hline $\begin{array}{l}\text { Solar } \\
\text { Insolation }\end{array}$ & $V_{P v}$ & $I_{P v}$ & $P_{P v}$ \\
\hline $1000 \mathrm{~W} / \mathrm{m}^{2}$ & 101 Volts & $13.5 \mathrm{Amp}$ & 1350 Watt \\
\hline
\end{tabular}

\begin{tabular}{|l|l|l|l|}
\hline $800 \mathrm{~W} / \mathrm{m}^{2}$ & 98 Volts & 10.9 Amp & 1068 Watt \\
\hline $600 \mathrm{~W} / \mathrm{m}^{2}$ & 96 Volts & $8.125 \mathrm{Amp}$ & 780 Watt \\
\hline
\end{tabular}

\section{CONCLUSION}

A generalized PV model of the PV cell, module, and array has been developed with MATLAB/Simulink and has been verified with a commercially available PV module. It considers sunlight irradiance and cell temperature as input parameters.

A Comparison between perturb and observe and incremental conductance MPPT methods using MATLAB/Simulink as modeling tool is presented. The simulation consists of the PV module, the irradiance, boost converter and MPPT controller. Suitability of two algorithms have been compared for the stand-alone solar PV system by considering variation in solar radiation.

An accurate electrical model of $72 \mathrm{w}$ solar panel was simulated by using MATLAB/Simulink. The power output for stand-alone system at standard as well as variable insolation has been demonstrated by using $\mathrm{P} \& \mathrm{O}$ and Incremental Conductance method. The comparison done between both the methods. The $\mathrm{P} \& \mathrm{O}$ methods shows the more decline in power with the variation in insolation. But in IC method, it tracks the MPP accurately to generate maximum power available by tracking MPP. The result shows the IC method is more accurate and efficient for MPPT as compare to P \& O method.

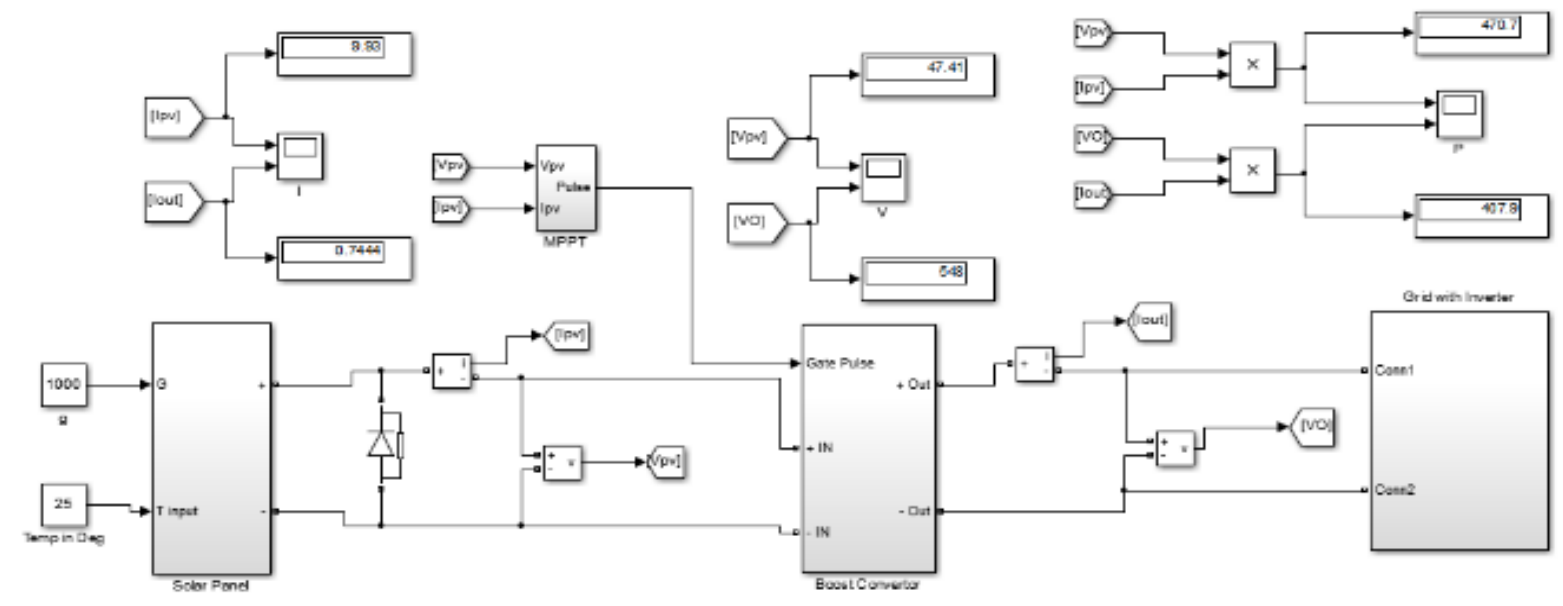

Fig. 21 MATLAB/Simulink diagram for Solar Maximum Power Tracking for Stand Alone System

\section{REFERENCES}

[1] P. S. Ravankar, W. Z. Gandhare, and A.G. Thosar, Government college of Engineering, Auranagabad, "Maximum Power Point Tracking for PV Systems using MATLAB/Simulink"2010, Second International Conference on Machine Learning and Computing.

[2] Solanki S. Chetan. Solar Photovoltaics: Fundamentals, Technologies and Applications, New Delhi, PHI, 2012.
[3] Erickson, R. W.; Maksimovic, D. Fundamentals of Power Electronics; Kluwer Academic Publishers, 2001.

[4] Villalva, M. G.; Gazoli, J. R.; Filho, E.R. Comprehensive Approach to Modelling and Simulation of Photovoltaic Arrays. IEEE Trans. PowerElec. 2009, 5, 1198-1208.

[5] Seyedmahmoudian, M.; Mekhilef, S.; Rahmani, R.; Yusof, R.; Renani, E. T. Analytical Modelling of Partially Shaded Photovoltaic Systems.MDPI J. Energ. 2013, 6, 128-144. 
[6] Kasa, N.; Lida, T.; Iwamoto, H. Maximum Power Point Tracking with Capacitor Identifier for Photovoltaic Power

[7] System. Proc. of EighthInternational Conference on Power Electronics, variable speed drives. 2000, 147, $130-35$.

[8] Xiao, W.; Dunford, W. G. A Modified Adaptive Hill Climbing MPPT method for photovoltaic power systems. Proceedings of 35th AnnualIEEE Power Electronics Specific Conference: 1957-63. 2004.

[9] Cavalcanti, M.C.; Oliveira, K.C.; Azevedo, G.M.S.; Neves, F.A.S. Comparative Study of Maximum Power Point Tracking Techniques forPhotovoltaic Systems. Electron Potencia 2007, 12, 163-171.

[10] Esram, T.; Chapman, L. P. Comparison of Photovoltaic Array Maximum Power Point Tracking Techniques. IEEE Trans. Energy Conv. 2007, 22,439-449.

[11] Safari, A.; Mekhilef, S. Simulation and Hardware Implementation of Incremental Conductance MPPT with Direct Control Method Using Cuk Converter. IEEE Trans. Ind. Elec. 2011, 58, 1154-1161.

[12] Yang Chih-Yu; Hsieh Chun-Yu; Feng Fu-Kuei; Chen Ke-Horng. Highly Efficient Analog Maximum Power
Point Tracking (AMPPT) in aPhotovoltaic System. IEEE Transaction on Circuits and Systems-1, 2012, 59.

[13] Sayed Khairy; Abdel-Salam Mazen; Ahmed Adel; Ahmed Mahmoud. New High Voltage Gain Dual-boost DC-DC Converter for Photovoltaic Power Systems. Int. J. Elec. Power Comp. Sys. 2012, 40, 711-728.

[14] De Brito, M.; Gomes, A.; Galotto, L.; Poltronieri, L.; Melo Guilherme de Azevedo e Melo, E.; Canesin, C. A. Evaluation of the Main MPPT Techniques for Photovoltaic Applications. IEEE Trans. Ind. Elec. 2013, $60,1156-1167$.

[15] Tey Kok Soon; Saad Mekhilef; Azadeh Safari. Simple and Low Cost Incremental Conductance Maximum Power Point Tracking Using Buck-Boost Converter. $J$. Renew. Sustain. Energ. 2013, 5, 023106.

[16] Houssam Issam; Locment Fabrice; Sechilariu Manuela. Experimental Analysis of Impact of MPPT Methods on Energy Efficiency for Photovoltaic Power System. $J$. Elec. Power Energy Syst. 2013, 46, 98-107.

[17] Kok Soon Tey; Saad Mekhilef, Modified Incremental Conductance Algorithm for Photovoltaic System Under Partial Shading Condition\& Load Variation. IEEE Trans. Ind. Elec. 2014, 61, 5384-5392. 